\title{
THE CIVIL JURY AND AMERICAN DEMOCRACY
}

\author{
PAUL D. CARRINGTON*
}

Herbert Bernstein, like others who admire European institutions, ${ }^{1}$ never acquired a taste for American civil procedure. ${ }^{2}$ Having taught him precisely that course at the University of Michigan Law School in 1965-66, I always took this as a personal failing on my part. What Herbert and others of his persuasion are unable to appreciate is the central importance in the American scheme of government of the right to jury trial in civil cases. As a tribute to him, I will explain one more time why that institution is indispensable and why it explains other features of American government that many international observers, and not a few Americans, find objectionable.

The importance of the institution is not measured by the number of civil jury trials, which is not great. It is, however, the right to jury trial that makes the rest of the constitutional scheme acceptable. ${ }^{3}$ And other institutional arrangements were structured around the concept of a democratic courthouse. In this essay, I will briefly account for how the civil jury came to America, why it is here to stay, and how other features of American civil litigation are linked to that central institution. My words are addressed in part to foreign lawyers who are not intimately familiar with American institutions.

I.

As most readers likely know, the common law jury emerged in the wake of the Norman Conquest of 1066. For those not familiar with the history of the institution, I briefly explain. The jury had

Copyright () 2003 by Paul D. Carrington.

* Professor of Law, Duke University. Herbert Bernstein was in my civil procedure class at the University of Michigan in 1965-66 and was my research assistant during the summer of 1966.

1. E.g., John H. Langbein, The German Advantage in Civil Procedure, 52 U. CHI. L. REV. $823(1985)$

2. Herbert L. Bernstein, Whose Advantage After All? A Comment on the Comparison of Civil Justice Systems, 21 U.C. DAVIS L REV. 587 (1988).

3. For an enthusiastic defense of the institution, see JefFrey Abramson, We, The JURY: THE JURY SYSTEM AND THE IDEAL OF DEMOCRACY (1994). 
roots in practices familiar to Anglo-Saxons brought to England from the continent a few centuries before the Normans arrived. ${ }^{4}$ For the Norman conquerors, it served as a means of securing participation by the indigenous subjects of a new monarchy in their judges' application of the lash of royal power. It was thus a source of social and political stability.

The ancient jury took two forms; the grand jury was an assembly summoned from the hundred (a unit of local government) or the larger shire to consider whether in an instance stated by the Crown a crime had been committed and, if so, who should be prosecuted. The petty jury was a smaller group of men summoned from the community to decide the guilt or innocence of a person so charged, or, increasingly as time passed to decide civil cases. Juries sat in the common law courts administered by the royal judges sent out from Westminster to bring the king's law to every shire of the realm.

The petty jury was increasingly used by the royal judges after 1215. In that year, a papal edict withdrew the clergy from the conduct of trials by ordeal, a method by which the royal courts had previously invoked supernatural forces to resolve disputed matters. ${ }^{6}$ When that device was withdrawn, the Crown issued a writ acknowledging that his judges were on their own to devise an alternative. ${ }^{7}$ No longer permitted to share the odium of decision with the divinity, the royal judges resorted to the jury as a standard feature of their process, thus substituting the community for the divinity as their partner in bearing the weight of moral responsibility for many of their decisions.

Over the nine centuries in which the jury has been in use, it has been radically transformed. ${ }^{8}$ Its one constant feature has been its status as a representative of the community being governed. Its one constant function has been to lighten the burden of moral and political responsibility otherwise borne by the judiciary, diffusing that responsibility through the community and thereby strengthening the courts. William Blackstone, so widely read in America, expressed the

4. John P. DAWSON, A History OF LAY JUDGES 35-115 (1960).

5. Edith Guild Henderson, The Background of the Seventh Amendment, 80 HARV. L. REV. 289 (1968).

6. The Fourth Lateran Council was the author.

7. Charles L. Wells, Origin of the Petty Jury, 3 L. Q. R. 97 (1911).

8. See ThOMAS ANDREW GREen, VERDICT ACCORDING TO CONSCIENCE: Perspectives ON THE ENGLiSH CRIMINAL TRIAL JURY, 1200-1800, at 105 (1985). 
belief that the $18^{\text {th }}$ century jury "ever has been, and I trust ever will be, looked upon as the glory of the English law."

In its thirteenth century form, jurors were subjects drawn from the community in which the dispute arose; they were identified as the persons most familiar with the events in question who could thus decide a dispute on the basis of their personal knowledge. They were, in a sense, the witnesses.

By the eighteenth century when Blackstone wrote, the petty jury had been transformed again. While still drawn from the community, its members were called to decide factual issues on the basis of evidence adduced by the parties. The royal judge performed a limited role as the presiding officer at a jury trial. This was very important to the English monarch because the royal judges were few in number and were drawn from the landed gentry.

The royal judge thus merely instructed the jury on the law they were called to enforce and ruled on objections by parties to the admission of evidence presented by an adversary. He also wielded the contempt power, i.e., the authority to impose summary punishment on any subject who disturbed the decorum of the King's court. ${ }^{10}$ But because he was usually merely a facilitator of decisions and was so seldom required to take primary responsibility for a decision, the King's judge (and thus the King) was usually able to avoid the odium of responsibility for results.

The royal judge from Westminster would be sitting in the community in which the dispute arose and from which the jury was drawn. A list or array of persons from which the jurors would be selected was assembled by a local court officer on the basis of his personal knowledge of the community and advice from clergymen and other community leaders. They were, it has been said, "the Rotarians of their day;" "11 that is to say that they were persons of good repute in their communities. Some were then selected from the array by lot and summoned as members of a venire who presented themselves as persons available for jury service in a particular case. They might be interrogated by counsel or the judge to explore possible disqualifying bias, for those who knew too much about the parties or events were by the eighteenth century excluded from service. Also, counsel would be allowed to strike a number from the panel without stating a reason

\footnotetext{
9. William BLACKSTONE, 3 COMMENTARIES ON THE LAW OF ENGLAND 379 (1768).

10. RonAld L. GoldFARB, THE CONTEMPT POWER 74-75 (1963).

11. Morris S. Arnold, The Civil Jury in Historical Perspective, in THE AMERICAN CIVIL JURY 9 (1987).
} 
for his objection, thus affording the parties a measure of authority over those who would decide their case. ${ }^{12}$

Twelve jurors would be selected as the petty jury to hear evidence presented by the parties and to decide the case. That number was large enough to render individual members non-visible, but not so large as to separate them from a sense of personal responsibility for the decision. After hearing the parties and receiving legal instructions from the judge, they retired to a private place for deliberation and then returned a verdict. They were required to be unanimous; the effect of this rule was to place moral pressure to agree on those who were prone to dissent, but yet to allow dissent as a means of recognizing an uncertainty about the appropriate result so profound that no satisfactory decision could be reached.

The petty jury was not available in all English courts. The Court of Chancery, exercising its extraordinary power as the King's conscience, sat only at London and therefore had no access to local jurors. $^{13}$ Also sitting in London were three other royal courts of enduring significance. The High Court of Admiralty had jurisdiction over matters arising at sea or involving maritime transactions. ${ }^{14}$ The Court of the Constable and Marshal had jurisdiction over matters of transnational importance. ${ }^{15}$ Also, after the break with the Pope, a court with ecclesiastical origins was formed to administer family and probate law. ${ }^{16}$

II.

Whether or not the jury was the glory of English law as Blackstone affirmed, it was increasingly important to American colonists because their relationship with the royal judges sent from England became strained. The right to jury trial was prescribed in the royal charters, which governed each colony. In Puritan New England, where lawyers were scarce, experienced juries heard evidence and

12. Barbara Allen Babcock, Voir Dire: Preserving "Its Wonderful Power," 27 STAN. L. REV. 545, 551 n.20 (1975).

13. For a brief account of the theory and development of The Court of Chancery, see JOHN HAMILTON BAKER, AN INTRODUCTION TO ENGLISH LEGAL History 112-34 (3d ed. 1990). The Court was presided over by a chancellor who embodied both jury and judge; the chancellor's justice has developed into what is now called "equity." Id.

14. For an account of the High Court of Admiralty, see Timothy J. Runyan, The Rolls Oleron and Admiralty Court in Fourteenth Century England, 19 AM. J. LEGAL. HIST. 95 (1975).

15. See BAKER, supra note 13, at 135 n.11.

16. For a brief account of the courts administering family and probate law, see DANIEL R. Coquillette, The ANglo-AmericAn Legal HeritAge 209-10 (1999). 
rendered verdicts without the burden of hearing from lawyers. ${ }^{17}$ Elsewhere, jury practice adhered to the English tradition. In all the colonies, the institution was seen as a bulwark against the intrusive tyranny of the King's judges. ${ }^{18}$

All of the eleven state constitutions ratified before 1787 retained charter provisions for the right to trial by jury in both criminal and civil cases, ${ }^{19}$ and the institution was retained as well in Rhode Island and Connecticut pursuant to their royal charters still in force. Some constitutions also provided for the grand jury as the source of criminal indictments. ${ }^{20}$ Although the new judges being selected in the former colonies did not represent the despised monarchy, they were persons of no marked special status, yet they were assigned the large political role of enforcing the state constitutions, interpreting democratic legislation, and shaping the common law. This was an extraordinary amount of power to confer on the fairly ordinary folks who were to be the judges.

The Constitution of the United States, as proposed in Philadelphia in 1787 , included a provision for a right to jury trial in any criminal proceeding brought in any federal court established pursuant to Article III, ${ }^{21}$ but it was silent about the mode of trial in civil cases. The demand for such a right in civil cases was at the top of the agenda of the Anti-federalists, ${ }^{22}$ who could readily foresee that the federal judiciary would play a large and potentially anti-democratic role, a political role much larger than that traditionally played by the English judiciary. Their demand was granted in the Seventh Amendment.

17. Jerold S. Auerbach, Justice Without LAw? 19-46 (1983).

18. Charles Wolfram, The Constitutional History of the Seventh Amendment, 57 MINN. L. REV. 639 (1973) (examining the development of the Seventh Amendment right to trial by jury); Stanton D. Krauss, The Original Understanding of the Seventh Amendment Right to Jury Trial, 33 U. RICH. L. REV. 407 (1999) (arguing that the intent of the Seventh Amendment was to preserve the right to jury trial that existed under the English common law).

19. For a compilation of early state constitutions, see THE CONSTITUTIONS OF THE UNITED STATES OF AMERICA (E. Duycinck ed., 1820).

20. See 1 Sara Beale \& William C. Bryson, Grand Jury law \& Practice 1-41 (1986) (describing the historical development of grand juries).

21. U.S. CONST. art. III, § 2, cl. 3.:

The Trial of All Crimes, except in cases of impeachment, shall be by jury; and such Trial shall be held in the State where the said Crimes shall have been committed; but when not committed within any State, the Trial shall be held at such Place or Places as the Congress may by Law have directed.

22. See The ANTIFEDERALISTS 49-51, 231-33, 238-64, 397-98, 413-15 and passim (Cecelia M. Kenyon ed., 2d prtg. 1985). See especially the remarks of Patrick Henry. Id. at 238-63. 
The Fifth Amendment also provided for indictment by grand jury in criminal cases prosecuted in federal court. ${ }^{23}$

It is possible that the failure to include a guarantee of civil jury trial in the Constitution, as proposed by the Philadelphia Convention, was related to the enlarged concern of its members for English creditors whose rights had been assured by the peace treaty. It is generally assumed, and not without reason, that juries are prone to favor civil litigants who are members of the community whom they represent. Insofar as it was the purpose of the Constitution to give comfort to the foreign creditors with claims against local American debtors, who were at that moment agitated by economic deflation, it made sense to say nothing about the right to trial by jury in actions seeking to enforce contracts and mortgages. But farmers and debtors would not tolerate suppression of their right to invoke the judgments of their neighbors, so the federal Constitution was amended to assure that judgments rendered against them would rest on verdicts made by juries. $^{24}$ It was especially important to impose the right to jury trial on the federal judiciary because they would be appointed "for good behavior" by a distant President of the United States. Indeed, at the Constitutional Convention there had been stout resistance to the creation of any federal court other than the Supreme Court, and a constitution was possible only if there were a compromise on that point, and so Congress was grudgingly authorized to create such judgeships.

It was important that the Seventh Amendment limited the right to jury trial to "suits at common law." This was taken to mean that there is no right to jury trial when a federal judge is exercising prerogatives inherited from the English Court of Chancery in "suits in Equity." 25 So it remains the law in the federal courts and in most (but not all) states that there is no right to demand for jury trial in proceedings that would have been brought in Chancery, or in the other English courts in which juries did not sit. Most important among cases so classified in the federal courts are suits for injunctions. While the distinction might be seen to be sensible as applied to that class of

23. U.S. CONST. amend. V ("No person shall be held to answer for a capital, or otherwise infamous crime, unless on a presentment or indictment of a Grand Jury ....")

24. Matthew P. Harrington, The Economic Origins of the Seventh Amendment, 87 IowA L. REV. 145 (2001) (arguing that the right to a civil jury was developed for functional reasons).

25. Fleming James, Jr., Right to a Jury Trial in Civil Actions, 72 YALE L. J. 655, 657-64 (1963) (outlining the historical test for trial by jury). 
cases, it is in other respects anachronistic because law and equity are seldom distinguished for any other purpose. ${ }^{26}$

In criminal law, the jury had sometimes performed the function of nullifying oppressive laws imposed by the Crown. In democratic America, it was still thought necessary to frustrate corrupt or otherwise ill-motivated prosecutions. ${ }^{27}$ Because the jury is numerous and transitory, it is almost invulnerable to bribery or intimidation. As has been said, it is the one institution in government that has no ambition of its own. ${ }^{28}$ In these respects, the jury serves much the same purpose as the separation of powers among the three branches of government. Indeed it constitutes yet another separation of power, this within the judicial branch. ${ }^{29}$

In its role in civil proceedings, the jury performs a comparable function by rendering the legislators who make the controlling law doubly accountable to the people, who first elect their lawmakers and are then called to administer the laws those representatives make. Law departing too far from the common understanding, from common sense, or from commonly shared moral values tends to be modified in its enforcement by civil juries to fit common habits of mind. This accountability was also applicable to judges making the common law.

In both criminal and civil matters, the presence of the jury shapes the function of the American judge. Francis Lieber, a German émigré, published in 1852 a widely read book, Civil Liberty and Self Government, comparing American legal institutions with those he had observed on the Continent. He especially celebrated the civil jury as an instrument of democratic government for its effect on the role of the judge, noting that:

It allows the judge to stand, as the independent organ of the law, not only above the parties, hostilely arranged against each other, but also above the whole practical case before the court. ${ }^{30}$

26. Id. at 663-64. See also Chauffers, Teamsters \& Helpers Local 391 v. Terry, 494 U. S. $558,575-76$ (1990) (Brennan J.) ("[S]ince the existence of a right to jury trial therefore turns on the nature of the remedy, absent congressional delegation to a special decisionmaker, there remains little purpose to our rattling through dusty attics of ancient writs.").

27. Clay S. Conrad, Jury Nullification: The Evolution of a Doctrine 45-64 (1998) (explaining the use of jury nullification in America). $87,106$.

28. Stephen Yeazell, The New Jury and the Ancient Jury Conflict, 1990 U. CHI. LEGAL F.

29. Id.

30. Francis Lieber, Civil LibERTY AND SELF-GovernMENT 234 (2d ed. 1874). 
He also approved of the jury as a device for securing "a mean of views of facts, regarding which Aristotle said that many persons are more just than one," but without "the disadvantages and the injustice of vague multitudes." "31

Lieber was also mindful of the secondary consequences of the jury for the political system as a whole. He observed that it makes the judge "a popular magistrate looked up to with confidence and favor." 32 And that it "makes the administration of justice a matter of the people" and thereby "awakens confidence" in the law..$^{33}$ By giving the citizen "a constant and renewed share in one of the highest public affairs," he noted, it "binds the citizen with increased public spirit to the government of his commonwealth." ${ }^{34}$ Thus, he thought, it is a great institution for the development of the "love of the law" that Montesquieu and others had identified as the essential spirit of a republic. $^{35}$ Tocqueville had expressed the same thought in describing the civil jury as a "gratuitous public school, ever open" that elevates the political good sense of jurors. ${ }^{36}$

While Tocqueville and Lieber might be thought to have romanticized the benign effects of the jury, there is strong empirical evidence that jurors almost universally take their duties very seriously. ${ }^{37}$ Moreover, few persons who have experienced the role of juror have left the courthouse without a sense of satisfaction that they have performed a worthy public service. Doubtless for many, that satisfaction is mixed with a sense of having been inconvenienced, perhaps unnecessarily, and sometimes with frustration or disappointment, but even then there is evident bonding of the citizen-juror to the community.

To some extent, the impulse to satisfaction is explained as an application of a principle well known to social psychologists as the need to resolve cognitive dissonance: ${ }^{38}$ persons exercising power are prone

31. Id. at 235-37.

32. Id.

33. Id.

34. Id.

35. Charles de Second, Baron de Montesquieu, The Spirit of Laws 29-31 (Thomas Nugent trans., University of California, Berkeley 6th ed. 1977) (1748).

36. AleXIS DE Tocoueville, 1 Democracy IN AMERICA 312 (Henry Reeves trans., undated) (1835).

37. See Harry Kalven, Jr. \& Hans Zeisel, The American Jury 3-11, 141-62 (1966); Shari S. Diamond, What Jurors Think, in VERDICT: AsSESSING THE CIVIL JURY SYSTEM 282 (Robert E. Litan ed., 1993).

38. The term was fashioned by Irving Goffman. It forms the subject of JACK W. BREHM \& ARTHur R. COHEN, EXPLORATIONS IN COGNITIVE DisSONANCE (1962). 
to resolve their anxieties by concluding that they have done the right thing. On that account, a republic trusting its citizens to sit as jurors is more likely to be trusted by them, and on that account is more likely to remain a republic. It is quite possible that Americans tolerate the enlarged role of the judiciary in their political system because of the trust derived from the existence of the civil jury. ${ }^{39}$

For all these reasons, the jury is here to stay in America. Judges like it $;{ }^{40}$ indeed in a very recent survey of 900 federal judges, only one percent responded with the opinion that the jury system is in poor condition and needs overhaul. ${ }^{41}$ Despite vigorous public relations campaigns misinforming the public about the jury, ${ }^{42}$ and despite frequent public disagreement with heralded verdicts, citizens also like it, or at least prefer it to the alternatives. ${ }^{43}$ Elected officers who care about their re-election are therefore no more likely to challenge the civil jury than they are to question the practice of electing legislators.

\section{III.}

Few Americans have ever seriously questioned the use of the jury in criminal cases. While questions of its administration are raised and debated from time to time, usually in the aftermath of a celebrated trial, ${ }^{44}$ there has never been a serious proposal to deny access to a jury for those accused of crime.

\footnotetext{
39. Yeazell, supra note 28, at 111-17.

40. Paula L. Hannaford, B. Michael Dann \& G. Thomas Munsterman, How Judges View Civil Juries, 48 DePAul L. REV. 247 (1998).

41. See generally Allen Pusey, Judges Rule in Favor of Juries: Survey by Morning News, DALlas MORNing NeWS, May 7, 2000, at 1J.

42. Stephen Daniels \& Joanne Martin, Civil Juries and The Politics of Reform (1995) (examining common political rhetoric through the use of empirical data); ELLEN E. SWARD, THE DECLINE OF THE CIVIL JURY 101-45 ( 2001) (arguing that procedural, structural and substantive changes in the law have diminished the role of the jury); Marc Galanter, News from Nowhere: The Debased Debate on Civil Justice, 71 DENV. U. L. REV. 77 (1993) (explaining that debate on jury reform is anchored on political myths); Marc Galanter, Real World Torts: An Antidote to Anecdote, 55 MD. L. REV. 1093, 1109-12 (1996) (debunking the assumption that juries are capricious and erratic); Michael J. Saks, Do We Really Know Anything About the Behavior of the Tort Litigation System - And Why Not? 140 U. PA. L. REV. 1147 (1992).

43. See Valerie Hans, Attitudes Toward the Civil Jury: A Crisis of Confidence, in VERDICT: ASSESSING THE CIVIL JURY SYSTEM 248, 277, supra note 37. See also Michael J. Saks, Public Opinion about the Civil Jury: Can Reality Be Found in The Illusions, 48 DEPAUL L. ReV. 221 (1998); Stephen J. Adler, The Jury Trial ANd ERror In the AMERICAN COURTroom 136-44 (1994).

44. E.g., Vincent Bugliosi, Outrage: The Five Reasons O. J. Simpson Got Away WITH MURDER (1996).
} 
The use of juries in civil cases has occasionally been questioned. Jerome Frank ${ }^{45}$ and Chief Justice Warren Burger, ${ }^{46}$ both twentieth century appellate judges holding life tenure, and neither of whom sat as a trial judge or practiced as a trial lawyer, were bold enough to criticize it as a source of irrationality. There is also some empirical evidence that appellate judges in American courts are likely to doubt the competence and integrity of juries. ${ }^{47}$ Corporate executives and some foreign litigants who find themselves litigating in American courts tend to fear juries, supposing that "anything can happen" in a jury trial. ${ }^{48}$ To that degree, the civil jury is controversial. ${ }^{49}$

The first point to be made is that many assumptions commonly made about juries are erroneous. The concern most frequently voiced is that the civil jury is xenophobic and afflicted with reverse class bias leading to irrational generosity to the poor and irrational hostility to wealthy multi-national corporations. Such assumptions disregard the undisputed fact that jurors, with few exceptions, take seriously their duties as officers of the law. There is solid evidence that American juries are less xenophobic than international litigants suppose. $^{50}$ There is also abundant evidence that their verdicts on the merits of cases presented to them correspond closely to the judgments that presiding judges would make on the same evidence. Jury awards for general damages are only marginally less predictable than, and correspond closely to, damages assessments by judges and lawyers. ${ }^{51}$ It is rare that a presiding judge disagrees strongly with a jury verdict. ${ }^{52}$ With respect to the fixing of compensatory damages, there is more of a difference. However, the evidence demonstrates that jury awards setting a value on pain and suffering are on average marginally higher

45. Jerome Frank, COURTS On TRIAL: Myth AND REALITY IN AMERICAN JUSTICE 11415 (1949).

46. Warren E. Burger, Thinking the Unthinkable, 31 LOY. L. REV. 205, 210-20 (1985).

47. Kevin M. Clermont \& Theodore Eisenberg, Anti-plaintiff Bias in Federal Appellate Courts, 84 JUDICATURE 128 (2000).

48. See norman F. CANTOR, Imagining the Law: COMmon Law AND the FOUNDATIONS OF AMERICAN LAW 227 (1997) ("In American courts - with juries waiting to sock it to big corporations with seemingly infinite deep pockets, and lax or populist or incompetent judges letting liability run riot - anything can happen.”).

49. See Symposium on The Jury, 54 SMU L. REV. 1681 (2001).

50. Kevin M. Clermont \& Theodore Eisenberg, Xenophilia in American Courts, 109 HARV. L. REV. 1120 (1996).

51. Roselle L. Wisler, Alice J. Hart \& Michael J. Saks, Decisionmaking About General Damages: A Comparison of Jurors, Judges and Lawyers, 98 MICH. L. REV. 751 (1999).

52. See Pusey, Judges Rule in Favor of Juries, supra note 41. Ninety-seven percent of the federal judges reported that they agreed with jury verdicts all or most of the time. 
than those assessed by judges,${ }^{53}$ but their awards estimating the value of future economic loss are marginally lower. ${ }^{54}$ And judges reduce jury awards that seem to them excessive. There is no evidence to support the belief that juries are influenced by the depth of a defendant's pocket, ${ }^{55}$ but juries seem prone to hold corporations to higher standards of conduct than they might impose on individual defendants. $^{56}$ This may reflect the not unreasonable belief that fictional persons enjoying immortality receive greater rewards from their conduct than do individual entrepreneurs engaged in the same conduct and have less justification for putting individuals at risk. On the other hand, juries are prone to be suspicious of personal injury claims, and are marginally less likely than judges to decide in favor of injured parties. $^{57}$

Any evaluation of the risks associated with juries should take account of the alternatives. All American judges are selected in part because of their political predispositions, and most are accountable in some way to the people they serve. It is not clear that they are on the whole materially less xenophobic or less class-biased than jurors, or even that they are more strongly committed to the disinterested enforcement of the law. Years of service on the bench can lead to moral fatigue and cynicism. To the extent that bribery or intimidation is a factor in American civil litigation, and they are not large factors, the concern is directed at judges, not jurors. Doubtless the decision to demand a jury or not is often informed by knowledge of the judge likely to try the case if a jury is not called.

53. Kevin M. Clermont \& Theodore Eisenberg, Trial by Jury or Judge: Transcending Empiricism, 77 CORNELl L. REV. 1124, 1126 (1992); Neil Vidmar \& Jeffrey J. Rice, Assessments of Noneconomic Damage Awards in Medical Malpractice Negligence: A Comparison of Jurors with Legal Professionals, 78 IowA L. REv. 883 (1993). Cf. Harry Kalven Jr., The Dignity of the Civil Jury, 50 VA. L. REV. 1055, 1063-68 (1964)(earlier study which placed jury awards at 20\% higher than those of judges).

54. James K. Hammit, Automobile ACCident Compensation: PAYMents by Auto INSURERS 45-46 (1985); JAMES S. KAKALIK ET AL., COSTS AND COMPENSATION PAID IN AVIATION ACCIDENT LiTigation 86-95 (1988); VAlERIE P. HANS \& NEIL VidMAR, JUdGing THE JURY 160-162 (1986).

55. See, e.g., NeIl Vidmar, Medical Malpractice AND the American Jury: CONFronting THE MYTHS ABOUT JURY INCOMPETENCE, DEEP POCKETS, AND Outrageous Damage Awards (1995); Valerie P. Hans \& William S. Lofquist, Jurors' Judgments of Business Liability in Tort Cases: Implications for the Litigation Explosion Debate, 26 LAW \& SOC'Y REV. 85 (1992).

56. Valerie P. Hans, The Illusions and Realities of Jurors' Treatment of Corporate Defendants, 48 DePAUL L. ReV. 322 (1998)

57. NAtional Center for State COURTS 2000 AnNual Report (2000) http://www.ncsconline.org/About_the_NCSC/PDFs/\%20ar.pdf (last visited Oct. 2, 2002). 
Other problems with the civil jury are less frequently observed but more substantial. Five seem worthy of note. The first is that jury trials are more costly, both in time and treasure, than "bench trials" in which the evidence is evaluated by a judge. There are more people in the courtroom. Even jurors are paid a modest fee. Their attention spans are more limited, requiring that evidence be received fewer hours a day, with more breaks. Documentary evidence must be more fully explained. There are likely to be more conferences between counsel and the court. A careful count suggests that a jury trial takes about half again as long in elapsed time as a bench trial.

For this and perhaps other reasons, the jury is seldom used today in civil cases in England, ${ }^{59}$ and almost as seldom in other Englishspeaking jurisdictions such as Canada and Australia. ${ }^{60}$ It bears notice, however, that those nations have quite different histories and political systems. In their traditions of parliamentary governments, the legislature is or was supreme and the political role of the courts was, until recent times, much diminished. They were therefore less in need of the moral support provided by community participation in decisions. ${ }^{61}$ As the judges of those countries are thrust (or have thrust themselves) into larger political roles, the wisdom of engaging civil juries to resolve some matters may regain its ancient visibility.

To some extent, the disadvantage in relative cost of a jury trial may be balanced by the economy of the judge's effort that must be invested in deciding cases without help of a jury. A judge deciding a case after trial without a jury must state his or her findings of fact and conclusions of law so that an appellate court can evaluate his or her decision. $^{62}$ In a complex case, this can be taxing work requiring careful review of the testimony transcript. Even in a simple case, the task of deciding a case without a jury is morally and emotionally more burdensome for the judge than presiding over a jury trial. It is not uncommon for months to elapse while the trial judge is working on the findings and conclusions. While jury deliberations can be pro(1959).

58. Hans Zeisel, Harry Kalven JR. \& Bernhard BuchHolz, Delay IN COURT 96

59. John BALdwin \& Michael MCCONVILle, JuRy TRials (1979).

60. Neil Vidmar, Canadian Criminal Jury: Searching for Middle Ground, 62 LAW \& CONTEMP. Probs. 141 (Spring 1999); Paul Byrne, Jury Reform and the Future, in THE JURY UNDER ATTACK 190 (Mark Findlay \& Peter Duff eds., 1988) (discussing the system in place in Australia).

61. P. S. Atiyah \& Robert Summers, Form And Substance in ANGlo-American LAW 198-335 (1987).

62. See, e.g., FED. R. CIV. P. 52. 
longed, they cannot forsake even temporarily the responsibility to reach a conclusion as judges sometimes do, and juries render verdicts in hours or days, not weeks or months.

A second problem is the indirect cost of the jury resulting from the need to control the process of proof by the imposition of the law of evidence, ${ }^{63}$ a corpus of law not known to the civil law tradition of continental Europe. The strictures on the admissibility of evidence are designed in part to protect laymen from beguilement and inflammation by sharp lawyering, but they serve also to complicate trials and are thus a source of added cost. They preclude the admission of some evidence that might be useful and enlarge the possibility of mistrial. Judges who hear evidence day after day are almost surely less vulnerable to lawyers' forensic tricks; hence, while the Federal Rules of Evidence apply to bench trials as well as jury trials, there is far less concern for the issues raised by their administration when there is no jury to hear the presentations.

Third, the jury imparts structural rigidity to civil procedure that is not encountered in other legal systems. Rigidity results from the need to present evidence orally and in a proceeding that is as compact and continuous as possible. Once a jury is assembled, a judge must be reluctant to grant prolonged adjournments making it doubtful whether the same jury can be reconvened. Parties and counsel who are required to present their evidence at such a compact hearing must be prepared, for the risk of surprise at trial is endemic. Accordingly, great importance was attached by common law courts to the pleadings by which the adversaries notified the court of the contentions they would advance at trial. While some cases were by consent tried without juries, the procedure employed adhered to the oral tradition required by the use of juries. Whether cases were to be tried with or without a jury, nineteenth century reforms were fashioned to compel parties to forecast the trial for one another in more specific detail. ${ }^{64}$ When that proved inadequate, twentieth century reforms expanded the use of discovery devices available to counsel seeking evidence for use at trial and foreknowledge of the adversary's evidence. American discovery practice, so distasteful to corporate defendants, whether American or otherwise, is thus a secondary consequence of the right

63. For an accessible current account, see ROGER C. PARK ET AL., EVIDENCE LAW: A STUDENT's GUIDE TO THE LAW OF EVIDENCE AS APPLIED to AMERICAN TRIALS (1998). For a comparative treatment, see MIRJAN R. DAMAšKA, EVIDENCE LAW ADRIFT (1997).

64. Charles E. Clark et Al., Handbook of the Code Pleading 54-58 (2d ed. 1947). 
to trial by jury in civil cases and the oral tradition associated with that right.

While the need for continuity and orality present problems, they are not without compensating advantages. Discontinuity can be a cause of delay in other legal systems, ${ }^{65}$ and heavy reliance on written presentations can diminish the satisfaction parties may obtain from the opportunity to present their contentions in open court to someone or some group who appear to take a serious interest in what they have to say. ${ }^{66}$ A jury trial, whatever its shortcomings, is a dramatic and not a bureaucratic event. Moreover, the drama is widely perceived to influence the integrity of witnesses; it is less stressful to sign a false affidavit than it is to lie in the presence of a judge, jury and adversary counsel. ${ }^{67}$

A fourth consequence of the civil jury is the emergence of a political constituency for laws administered by juries, particularly the law of torts as it has evolved in the fifty states. There are many who regret that development, especially those responsible for the welfare of manufacturing firms, virtually all of whom seek what they denote as tort law reform. ${ }^{68}$ It is true that American tort law is very expensive as a means of compensating harms to accident victims and consumers; substantially less than half the money paid by tort defendants is received by tort plaintiffs; the rest goes to lawyers and other participants in the process. ${ }^{69}$ Proponents of various schemes to displace tort law with less costly accident insurance are confronted with a deeply seated conservatism that may be in part associated with the self-reassuring experience of many Americans who have sat as jurors.

Finally, the right to jury trial in civil cases has numerous implications for the role of lawyers in litigation, who are cast as champions for their clients in a form of combat. As Lieber observed, it is the

65. Arthur Taylor von Mehren, Some Comparative Reflections on First Instance Civil Procedure: Recent Reforms in German Civil Procedure and in the Federal Rules, 63 NOTRE DAME L. REV. 609, 614-22 (1988).

66. John Thibaut \& Laurens Walker, Procedural Justice: A Psychological ANALYSIS (1975).

67. Richard L. Marcus, Completing Equity's Conquest? Reflections on the Future of Trial under the Federal Rules of Civil Procedure, 50 U. PITT. L. REV. 725, 757-62 (1989).

68. Their view was forcefully stated by Peter W. Huber, Liability: The Legal Revolution AND Its Consequences (1988) and Walter K. Olson, The Litigation EXPLOSION: WHAT HAPPENED WHEN AMERICA UNLEASHED THE LAWSUIT (1991).

69. See generally AlFREd F. CONARD ET AL., ACCIDENT COSTS AND PAYMENTS: STUdies IN THE ECONOMICS OF INJURY 248-52 (1964). 
source of the adversary tradition and thus shapes the membership and ethics of the American legal profession. ${ }^{70}$

The civil jury in the federal courts now responds to somewhat different needs than those animating the Anti-federalists in 1788. Presidents and Senators are now directly elected by the people, whereas they were not in 1788; these changes diminished somewhat the need for citizen participation. Also, the communities that existed in the eighteenth century were much stronger than those now existing in the twenty-first century. America is much more an aggregation of individuals than of communities and the conception of a verdict as an expression of community values has less to commend it. On the other hand, the federal courts play a much larger role in the political system and in the American national life than they did at an earlier time; in this respect the need for separation of powers within the judiciary has been steadily elevated. And increased individualism elevates the need of the legal system for roots in the morality of the public it serves even if those community roots must be artificially constructed.

Citizen participation in the disposition of civil cases has been an important, indeed central, and perhaps critical, element in the development of the American legal system. To abandon that idea would require deep constitutional change in the social and political structure. The system has served many purposes, but its enduring purpose has been to secure a greater measure of trust in judicial institutions. ${ }^{71}$

Japan is presently introducing lay participation in criminal proceedings in its courts and contemplates extension of the use of lay citizens in civil matters. Perhaps the Japanese are in this respect headed in the right direction. ${ }^{72}$ I am not here advocating the civil jury for Japan or any other country, but I am certain that democracy is needed at the American courthouse.

Quite possibly as Bernstein believed, there is a German advantage in civil procedure if the matters to be litigated are contracts between businessmen. Leaving such cases to highly professional judges who will control the proceedings may make a lot of sense. That advantage is less apparent when one considers other kinds of cases having larger political consequences, or where the class or political

70. LIEBER, supra note 30.

71. See generally Paul D. Carrington, The Role of the Jury in Civil Dispute Resolution, 1990 U. CHI. LeGAL F. 1.

72. The Justice System Reform Council, Recommendations for the Justice System Reform Council - For a Just System to Support Japan in the $21^{s t}$ Century, at http://www.kantei.go. jp/foriegn/judiciary/2001/0612report.html (June 12, 2001). 
biases of the judge have more bearing. It is still less apparent if one accepts the reality that all American judges are politicians before they are judges. And in a highly diverse society that has always been under great centrifugal force, the advantage lies with a system that democratizes the courthouse, that trusts its citizens to participate in making consequential decisions, and places the legal profession and its judges in a subordinate relationship to the people. 